\title{
Review \\ The Role of Mitochondria-Derived Peptides in Cardiovascular Diseases and Their Potential as Therapeutic Targets
}

\author{
Siarhei A. Dabravolski ${ }^{1, *}$, Nikita G. Nikiforov ${ }^{2,3}$, Antonina V. Starodubova ${ }^{4,5}$, Tatyana V. Popkova ${ }^{6}$ and \\ Alexander N. Orekhov 2,3 (D) \\ 1 Department of Clinical Diagnostics, Vitebsk State Academy of Veterinary Medicine [UO VGAVM], \\ 7/11 Dovatora Str., 210026 Vitebsk, Belarus \\ 2 Laboratory of Cellular and Molecular Pathology of Cardiovascular System, Institute of Human Morphology, \\ 3 Tsyurupa Street, 117418 Moscow, Russia; nikiforov.mipt@googlemail.com (N.G.N.); \\ a.h.opexob@gmail.com (A.N.O.) \\ 3 Laboratory of Angiopathology, The Institute of General Pathology and Pathophysiology, 8 Baltiyskaya Street, \\ 125315 Moscow, Russia \\ 4 Federal Research Centre for Nutrition, Biotechnology and Food Safety, 2/14 Ustinsky Passage, \\ 109240 Moscow, Russia; avs.ion@yandex.ru \\ 5 Therapy Faculty, Pirogov Russian National Research Medical University, 1 Ostrovitianov Street, \\ 117997 Moscow, Russia \\ 6 V.A. Nasonova Institute of Rheumatology, 34A Kashirskoye Shosse, 115522 Moscow, Russia; \\ popkovatv@mail.ru \\ * Correspondence: siarhei.dabravolski@vsavm.by
}

check for updates

Citation: Dabravolski, S.A.; Nikiforov, N.G.; Starodubova, A.V.; Popkova, T.V.; Orekhov, A.N. The Role of Mitochondria-Derived Peptides in Cardiovascular Diseases and Their Potential as Therapeutic Targets. Int. J. Mol. Sci. 2021, 22, 8770. https://doi.org/10.3390/ ijms 22168770

Academic Editor: Anna Atlante

Received: 25 July 2021

Accepted: 13 August 2021

Published: 16 August 2021

Publisher's Note: MDPI stays neutral with regard to jurisdictional claims in published maps and institutional affiliations.

Copyright: (c) 2021 by the authors. Licensee MDPI, Basel, Switzerland. This article is an open access article distributed under the terms and conditions of the Creative Commons Attribution (CC BY) license (https:/ / creativecommons.org/licenses/by/ $4.0 /)$.

\begin{abstract}
Mitochondria-derived peptides (MDPs) are small peptides hidden in the mitochondrial DNA, maintaining mitochondrial function and protecting cells under different stresses. Currently, three types of MDPs have been identified: Humanin, MOTS-c and SHLP1-6. MDPs have demonstrated anti-apoptotic and anti-inflammatory activities, reactive oxygen species and oxidative stressprotecting properties both in vitro and in vivo. Recent research suggests that MDPs have a significant cardioprotective role, affecting CVDs (cardiovascular diseases) development and progression. CVDs are the leading cause of death globally; this term combines disorders of the blood vessels and heart. In this review, we focus on the recent progress in understanding the relationships between MDPs and the main cardiovascular risk factors (atherosclerosis, insulin resistance, hyperlipidaemia and ageing). We also will discuss the therapeutic application of MDPs, modified and synthetic MDPs, and their potential as novel biomarkers and therapeutic targets.
\end{abstract}

Keywords: mitochondria-derived peptides; cardiovascular diseases; Humanin; MOTS-c; SHLPs; atherosclerosis; insulin resistance; hyperlipidaemia; ageing

\section{Introduction}

MDPs are a class of recently identified peptides, which are found within other known mitochondrial genes and encoded by small ORFs (open reading frames). The first MDP, $\mathrm{HN}$ (Humanin), was discovered in 2001 in patients with Alzheimer's disease and described as a neuroprotective peptide with a high therapeutic potential for neurodegenerative diseases [1,2]. After HN, two other types of MDPs were discovered: MOTS-c (mitochondrial ORF of the $12 S$ rDNA type-c) [3] and SHLP (small Humanin-like peptide, 1 to 6) [4]. MDPs are widely presented in different tissues, such as the kidney, skeletal muscle, colon, vascular wall and heart. MDPs are released into the body via paracrine and endocrine pathways and have diverse functions as cytoprotective agents, such as maintaining cell viability and mitochondrial function under stress, are involved in cellular metabolism and cell survival and act in response to inflammation and OS (oxidative stress) [5]. Recently, the role of MDPs was highlighted for many senescence and ageing-associated diseases, chronic inflammation diseases, cancer and neurodegenerative diseases and retinal and fertility diseases (reviewed 
in [6-10]). In this review, we focus on the role of on MDPs as crucial peptides, modulating and regulating mitochondrial function and involved in pathological changes in CVD via different molecular mechanisms. We also discuss the application of MDPs, modified MDPs and synthetic MDPs as uprising pharmaceutical tools for the treatment of CVD and other diseases. Further understanding the role of MDPs in various signalling pathways related to CVD would improve its medical significance and therapeutic potential.

\section{MDP General Description}

\subsection{Mitochondrial Genome Overview}

Mitochondria are complex organelles of bacterial origin, playing important roles in cellular signalling, energy production and metabolism. Mitochondria are known as partially autonomous organelles with their own genome, responsible for the synthesis of 4 out of 5 enzyme complexes of OXPHOS (oxidative phosphorylation) (complexes I, III, IV and V), 2 rRNAs (12S (small) and 16S (large)) and 22 tRNA (transfer RNA) to carry out intramitochondrial protein synthesis. MtDNA is compactly packed with only a regulatory D-loop non-coding region, which contains replication initiation sites and $\mathrm{H}$-strand transcription promotors [11]. Many nuclear-encoded proteins are transported into mitochondria and required for proper functioning; however, some proteins are targeted back to the nucleus (so-called retrograde signalling) to influence nuclear gene expression [12]. Recently, researchers have found in the rRNA locus hidden ORFs that could be transcribed and translated into short peptides with outstanding biological properties [5]. Here, we will provide the known functions of these MDPs.

\subsection{MDPs Generation and Functions}

HN was the first identified MDP, encoded by an ORF in the 16S rRNA of mtDNA and translated into the 21 (in mitochondria) or 24-amino-acid peptide (in the cytoplasm). Despite the different lengths, 21 and 24-amino-acid peptides have similar biological functions. This polypeptide is conserved across species and involved in cell protection, antiapoptosis, anti-inflammation and anti-oxidation, regulating mitochondrial biogenesis and functions [13-15], and activation of chaperon-mediated autophagy (via interaction with HSP90 (heat shock protein 90)) [13]. Wider investigation of different genomes provided data that the Humanin genes in many species are under pseudogenization but not in humans [16]. Furthermore, closer examination of the genomes of mice suggests that some nuclear genes could produce different Humanin-like peptides in different tissues and in different developmental stages and be involved in the regulation of mitochondria biogenesis [17]. The avian mitochondrial genome also contains conserved homologues of humanin and SHLPs, and, additionally, two new sORF (small open reading frames) called av-scO1 and av-scO2 (avian strongly conserved sORFs 1 and 2), encoding 17 and 25 amino-acid peptides, respectively [18]. Similarly, it was suggested that the human mitochondrial genome may carry more MDPs and some Humanin-like peptides are located inside many nuclear genes [19].

MOTS-c is the second identified 16 amino-acid MDP encoded by mtORF in the $12 \mathrm{~S}$ rRNA gene. The best-known function of MOTS-c is based on the activation of AMPK (AMP-activated protein kinase); thus, MOTS-c regulates energy metabolism that could ameliorate IR (insulin resistance), diabetes, diet-induced obesity and other similar diseases [3]. Additionally, MOTS-c was shown to protect against coronary endothelial dysfunction by reduction of the release of several pro-inflammatory cytokines (TNF- $\alpha$ (Tumor Necrosis Factor-Alpha), IL-6 (Interleukin), IL-1 $\beta$ ), adhesion molecules E-selectin, VCAM-1 (Vascular Cell Adhesion Molecule 1), ICAM-1 (Intercellular Adhesion Molecule) and inducible enzymes (COX2 (Cyclooxygenase-2), iNOS (Nitric Oxide Synthase 2A (Inducible, Hepatocytes))), thus inhibiting the MAPK/NF- $\mathrm{B}$ pathway (mitogen-activated protein kinase/nuclear factor kappa-light-chain-enhancer of activated B cells) [20]. Interestingly, MOTS-c was also described as a specific retrograde regulator of nuclear gene expression via its interaction with several transcription factors [21]. Such MOTS-c activity was detected 
as a response to metabolic stress and, possibly, may be involved in the development of age-related diseases and regulation of human longevity [22].

SHLP1-6 (small Humanin-like peptides) were discovered in the same 16S rRNA as Humanin. While encoded by the same ORFs, they all have different biological functions. Among them, SHLP2 and SHLP3 are functionally the most similar to HN, with maximal expression in the spleen, kidney and liver, known as cytoprotective peptides [4]. SHLP1 was detected in the heart, SHLP2 in muscles and SHLP3 in the brain. The circulating level of SHLP2 in the blood is age-dependent, suggesting its role in the progression of age-related diseases and longevity. Recently, it was found that SHLP2 has chaperone-like properties, could increase the amounts of pancreatic cells and improve mitochondrial bioenergetics [23]. SHLP2 could also protect from age-related degeneration of macular cells via improved mitochondria functions and reduced apoptosis [24].

\subsection{Nuclear-Encoded sORF Microproteins That Act on Mitochondria}

Recently, several micropeptides acting on mitochondria were identified in nuclear sORFs. Thereby, a 54-amino-acid nuclear-encoded micropeptide called PIGBOS was shown to localize to the MOM (mitochondrial outer membrane) at the ER-mitochondria contact sites. PIGBOS interacts with the ER protein CLCC1 (Chloride Channel CLIC Like 1) and regulates UPR (unfolded protein response), and thus could be involved in the pathogenesis of many neurodegenerative disorders [25]. Another nuclear sORF-encoded micropeptide, MIEF1-MP (mitochondrial elongation factor 1 microprotein), was shown to localize to the mitochondrial matrix, interact with the mitochondrial ribosome and regulate the translation rate of the mitochondrial proteins [26]. Mitoregulin (also known as MPM (micropeptide in mitochondria) and MOXI (micropeptide regulator of $\beta$-oxidation)), a 56-amino-acid micropeptide encoded by long non-coding RNA (LINC00116), localizes to the MIM (mitochondrial inner membrane), where it binds cardiolipin and regulates $\mathrm{Ca}^{2+}$ metabolism, mitochondrial membrane potential, protein complex assembly and respiration rates [27]. Other functions of mitoregulin were defined in muscle cells, where it increases oxygen consumption, ATP production of mitochondria and could promote myogenic differentiation and muscle fibre growth [28] and fatty acid $\beta$-oxidation [29].

Interestingly, two Humanin-like nuclear genes (MTRNR2L2 and MTRNR2L8) are upregulated and activate a "cell survival" network in patients with CAD (coronary artery disease) after $60 \mathrm{~min}$ of hyperoxia [30]. However, analysis of SNPs (single nucleotide polymorphisms) in 13 gene regions of Humanin-like peptides have found no statistically significant associations with CAD [31]. SNPs in Humanin-like nuclear isoform genes could influence CAD development on other molecular (post-transcriptional or post-translational), temporal (initial or more advanced disease progression stage) or genetic (specific ethnic group or mitochondrial DNA haplogroup) levels; thus, further research is required to specify their role in heart cell metabolism and heart diseases development.

Hopefully, with further technological improvements in the area of mitochondrial genome sequencing and small proteins identification, more MDPs and nuclear sORFencoded micropeptides will be characterized and used as biomarkers or therapeutic targets.

\subsection{Connection to Cardiovascular Risk Factors}

Atherosclerosis, ageing, IR and hyperlipidaemia are the main risk factors for CVDs. As many researchers have shown, MDPs are closely associated with those risk factors.

Atherosclerosis: Atherosclerosis is a decades-lasting chronic inflammatory disease, which leads to the formation of foam cells, cholesterol accumulation in the arterial wall and is closely associated with CAD [32]. The foam cell formation is the initial stage of plaque development, which is based on the disbalance of the cholesterol influx and efflux in macrophages. Several receptors and transporters are involved in cholesterol transport and accumulation: CD36 (Fatty Acid Translocase), LOX-1 (Lectin-Type Oxidized LDL Receptor 1), ABCA1 (ATP-Binding Cassette Transporter A1) and ABCG1 (ATP-Binding Cassette Sub-Family G Member 1) [33]. Modified Humanin HNG (Gly [14]-Humanin 
with an amino-acid substitution at position 14 (Gly for Ser)) was shown to reduce the accumulation of Ox-LDL (Oxidized Low-Density Lipoprotein) by preventing CD36 and LOX-1 upregulation, and upregulate the expression of ABCA1 and ABCG1, thus preventing the formation of macrophage-derived foam cells [34]. Similarly, recent research has shown that HNG could directly suppress LOX-1 expression [35]. Other research defines that HNG also promotes autophagic degradation of Ox-LDL throughout lysosomal enzyme cathepsin $\mathrm{D}$ and its membrane protein receptor FPRL1 (Formyl Peptide Receptor-Like 1) [36].

Hyperglycaemia-induced endothelial dysfunction plays a key role in the development of diabetes-associated premature atherosclerosis and further cardiovascular complications. Under high glucose conditions, vascular endothelial cells produce high levels of proinflammatory cytokines, such as TNF- $\alpha$ and IL- $1 \beta$, ROS (reactive oxygen species) and high levels of VCAM-1 and E-selectin, which initiate atherosclerosis via adhesion of circulating leukocytes to the endothelium [37]. The reduced expression level of KLF2 (Krüppel-like factor 2), an essential regulator of endothelial functions, also was found to be closely related to hyperglycaemia-induced endothelial dysfunction. KLF2 protects endothelial cells via regulation of the angiogenesis, thrombotic activation and endothelial pro-inflammatory pathway [38]. As it was recently shown, Humanin treatment induces the expression of KLF2 and regulates the expression of the KLF2 target genes, such as eNOS (endothelial nitric oxide synthase) and ET-1 (endothelin-1). Humanin treatment also inhibits the high glucose-induced secretion of TNF- $\alpha$ and IL- $1 \beta$ and reduces the expression of VCAM-1 and E-selectin, thus preventing hyperglycaemia-induced attachment of the monocytes to the vascular cells, endothelial dysfunction and atherosclerosis progression [39].

Similar effects were shown for MOTS-c treatment, which decreased the expression levels of the AT-1 (angiotensin II type 1) and ET-B (endothelin B) receptors and increased the level of phosphorylated AMPK [40]. AT-1 is a crucial player in CVD and an important drug target; the high level of the AT-1 receptor leads to myocardial fibrosis, cardiac dysfunction and heart failure, while a decreased level of the AT- 1 receptor is associated with reduced oxidative stress, thus preventing the cardiac remodelling and development of myocardial contractile dysfunction [41]. Similarly, the MOTS-c level correlates with microvascular and epicardial endothelial function, and thus could be used as a marker for early coronary atherosclerosis [42] and CAD [43].

Ageing: In humans, plasma levels of MDPs (HN, MOTS-c and SHLP2) decline with age and correlate with mitochondrial dysfunction, rise in mitochondria-generated oxidative damage and development of age-related diseases (reviewed in [44,45]).

Cellular senescence is usually connected with the production of SASPs (senescenceassociated secretory phenotypes), which are required to attract immune cells to remove senescent cells. Administration of HN and MOTS-c to the senescent cells increases secretion of some SASP components and raises mitochondrial respiration, suggesting their cytoprotective role in mitochondria energy metabolism and therapeutic potential for the lifespan extension [46]. Similarly, MOTS-c and HN could stimulate the secretion of some SASP components (cytokines IL-1 $\beta$, IL-6, IL-8, IL-10 and TNF- $\alpha$ ) and make SASP-secreting senescent cells easier to detect and cleared by immune cells [8]. Recent research has shown that levels of HN, cytoprotective factor GDF15 (Growth Differentiation Factor 15) and major metabolic regulator FGF21 (Fibroblast Growth Factor 21) positively correlates with age in humans and could be considered as biomarkers of biological age [47] and age-associated diseases with known mitochondrial impairment [48].

Insulin resistance: Insulin resistance in the metabolic tissues is often associated with a decreased number of mitochondria and available oxidative enzymes, abnormal mitochondria morphology, reduced production of ATP and insulin-dependent glucose disposal $[49,50]$. Humanin administration was shown to increase insulin sensitivity in muscles and the liver, fatty acid metabolism signalling and insulin-mediated AKT-signalling (Protein kinase B) [51,52]. Treatment of Alzheimer's disease in a mice model (APP/PS1 transgenic mice, which is expressing a chimeric mouse/human amyloid precursor protein (Mo/HuAPP695swe) and a mutant human presenilin 1 (PS1-dE9), both directed at the cen- 
tral nervous system neurons) with HNG improved insulin sensitivity in the brain through the regulation of the IRS-1/mTOR (Insulin Receptor Substrate 1/mechanistic target of rapamycin) insulin signalling pathway in the hippocampus [53]. Similar to HN, SHLP2 and SHLP3 also have confirmed in vivo and in vitro insulin-sensitizing activities. The primary activity of SHLP2 and SHLP3 has been shown on adipose tissue, where they enhanced 3T3-L1 pre-adipocyte differentiation. Infused SHLP2 also increased the glucose uptake and suppressed hepatic glucose production, thus acting as both a central and peripheral insulin sensitizer [4].

MOTS-c promotes system-level insulin sensitivity via skeletal muscle, where it increases fatty acids $\beta$-oxidation and mitochondria biogenesis. Mechanically, MOTS-c acts throughout the AMPK, SIRT1 (Sirtuin 1) and PGC1 $\alpha$ (Peroxisome Proliferator-Activated Receptor Gamma Coactivator 1-Alpha) signalling pathways, and stimulates GLUT4 (Glucose Transporter Type 4, Insulin-Responsive) expression [54,55].

Hyperlipidaemia: Humanin is also one of the central regulators of peripheral lipid metabolism. HN treatment of human hepatocytes resulted in decreased lipid accumulation and downregulation of lipogenesis genes (SREBP1 (Sterol Regulatory Element Binding Transcription Factor 1), FAS (Fatty Acid Synthase), and SCD1 (Acyl-CoA Desaturase)). In addition to an enhanced AMPK phosphorylation-mediated effect on IR, HN also suppressed phosphorylation of the mTOR signalling pathway [56], the crucial regulator of response to stresses, protein synthesis, cell growth and proliferation, cell survival and cell cycle progression [57]. Injection of HNG was shown to decrease liver triglyceride accumulation, visceral fat and body weight gain in high-fat diet-fed mice [58]. Similarly, injections of HNG and SHLP2 in a diet-induced obesity mouse altered the concentrations of amino acid and lipid metabolites in plasma, acting mostly via the glutathione and sphingolipid metabolism pathways [59].

MOTS-c, acting mostly via skeletal muscle, targets the methionine-folate cycle and connected de novo purine biosynthesis, increases the AICAR (5-aminoimidazole-4-carboxamide ribonucleotide) levels and activates AMPK, thus ameliorating IR and diet-induced obesity [3]. On the molecular level, PGC- $1 \alpha$ regulates the involvement of MOTS-c in energy metabolism, where further MOTS-c activates AMPK, GLUT4 and ACC (Acetyl CoA carboxylase), stimulating mitochondria biogenesis and increasing the level of fatty acid $\beta$-oxidation [60]. In the D-galactose fed mice, MOTS-c treatment was shown to alleviate the lipid accumulation through improved mitochondria dynamics (achieved via altering mRNA levels of Drp1 (Dynamin-Related Protein 1) and mitofusins) [61]. Taking into account the ability of MOTS-c under different metabolic stresses to translocate to the nucleus and regulate the expression of many genes, primarily with ARE (antioxidant response elements) and TF (such as NFE2L2 / NRF2 (nuclear factor erythroid 2-related factor 2)) [21], it could be considered as a crucial player in the metabolism of glycolipids and a promising target for the treatment of metabolic diseases.

Discussed connections between MDPs and CVD risk factors are summarized in Table 1.

Table 1. Identified connections between MDPs and CVD risk factors.

\begin{tabular}{|c|c|c|c|}
\hline CVD Risk Factor & MDP & The Way of Action & References \\
\hline \multirow{5}{*}{ Atherosclerosis } & \multirow{3}{*}{ HNG } & $\begin{array}{l}\text { prevents } C D 36 \text { and } L O X-1 \text { upregulation; upregulates the } \\
\text { expression of } A B C A 1 \text { and } A B C G 1\end{array}$ & [34] \\
\hline & & suppress $L O X-1$ expression & [35] \\
\hline & & $\begin{array}{l}\text { promotes autophagic degradation of Ox-LDL throughout } \\
\text { lysosomal enzyme cathepsin D and its receptor FPRL1 }\end{array}$ & [36] \\
\hline & $\mathrm{NH}$ & $\begin{array}{l}\text { induces the expression of KLF2;inhibits the high } \\
\text { glucose-induced secretion of TNF- } \alpha \text { and IL- } 1 \beta \text {; reduces } \\
\text { the expression of VCAM- } 1 \text { and E-selectin }\end{array}$ & [39] \\
\hline & MOTS-c & $\begin{array}{l}\text { decreases the expression levels of the } A T-1 \text { and } E T-B \\
\text { receptors; increased the level of phosphorylated AMPK }\end{array}$ & [40] \\
\hline
\end{tabular}


Table 1. Cont.

\begin{tabular}{|c|c|c|c|}
\hline CVD Risk Factor & MDP & The Way of Action & References \\
\hline \multirow[t]{3}{*}{ Ageing } & \multirow[t]{2}{*}{ MOTS-c and HN } & $\begin{array}{l}\text { increase secretion of SASP components and rise } \\
\text { mitochondrial respiration }\end{array}$ & [46] \\
\hline & & $\begin{array}{l}\text { stimulate the secretion of SASP components (cytokines } \\
\text { IL-1 } \beta \text {, IL- } 6, \text { IL- } 8, \text { IL-10 and TNF- } \alpha \text { ) }\end{array}$ & [8] \\
\hline & $\mathrm{HN}$ & $\begin{array}{c}\text { increases insulin sensitivity in muscles and the liver; } \\
\text { increase fatty acid metabolism signalling and } \\
\text { insulin-mediated AKT-signalling }\end{array}$ & {$[51,52]$} \\
\hline \multirow[t]{6}{*}{ Insulin resistance } & & improves insulin sensitivity in the brain through the & \\
\hline & HNG & $\begin{array}{c}\text { regulation of IRS- } 1 / \text { mTOR signalling pathway in the } \\
\text { hippocampus }\end{array}$ & [53] \\
\hline & SHLP2 and SHLP3 & enhance 3T3-L1 pre-adipocyte differentiation & [4] \\
\hline & SHLP2 & $\begin{array}{l}\text { SHLP2 increased glucose uptake and suppressed hepatic } \\
\text { glucose production }\end{array}$ & [4] \\
\hline & MOTS-c & $\begin{array}{c}\text { increases fatty acids } \beta \text {-oxidation and mitochondria } \\
\text { biogenesis; stimulates GLUT4 expression } \\
\text { decreases lipid accumulation and down-regulates }\end{array}$ & {$[54,55]$} \\
\hline & $\mathrm{HN}$ & $\begin{array}{l}\text { lipogenesis genes (SREBP1, FAS and } S C D 1 \text { ); enhances } \\
\text { AMPK phosphorylation-mediated effect on IR; suppresses } \\
\text { phosphorylation of the mTOR signalling pathway }\end{array}$ & [56] \\
\hline \multirow[t]{6}{*}{ Hyperlipidaemia } & HNG & $\begin{array}{l}\text { decreases liver triglyceride accumulation, visceral fat and } \\
\text { body weight gain in high-fat diet-fed mice }\end{array}$ & [58] \\
\hline & HNG and SHLP2 & $\begin{array}{l}\text { acting via the glutathione and sphingolipid metabolism } \\
\text { pathways alter the concentrations of amino acid and lipid } \\
\text { metabolites in plasma }\end{array}$ & [59] \\
\hline & \multirow{4}{*}{ MOTS-c } & increases AICAR levels and activates AMPK & [3] \\
\hline & & $\begin{array}{l}\text { activates AMPK, GLUT4 and AC; stimulating } \\
\text { mitochondria biogenesis and increasing the level of fatty } \\
\text { acid } \beta \text {-oxidation }\end{array}$ & {$[60]$} \\
\hline & & improves mitochondria dynamics & [61] \\
\hline & & regulates expression of ARE and NFE2L2/NRF2 & [21] \\
\hline
\end{tabular}

\subsection{Mechanisms of Action}

The main therapeutic properties of MDPs are anti-inflammation and anti-apoptosis, offering protection from OS and ER stress. In the following, we briefly discuss the molecular mechanism of these pathways.

Anti-inflammatory mechanism: The anti-inflammatory effect of MOTS-c treatment relies on inhibition of pro-inflammatory cytokines (IL-1 $\beta$, IL-6 and TNF $\alpha$ ) through decreased phosphorylation of MAPK and upregulating the levels of TF STAT3 (signal transducer and activator of transcriptional 3) and AhR (aryl hydrocarbon receptor) in macrophages [3,62]. STAT3 and AhR are involved in many cellular biological processes via the regulation of anti/proinflammatory responses [63,64]. Similarly, the HN treatment resulted in the inhibition of the expression of $I L-1 \beta$ and $I L-18$ and prevented AMPK-mediated NLRP3 (NOD-, LRR- and pyrin domain-containing protein 3) inflammasome activation [65]. The NLRP3 inflammasome plays a central role in the pathophysiology of atherosclerosis and CAD development $[66,67]$. On the contrary, SHLP3 treatment increased the levels of IL-6 and MCP-1 (monocyte chemotactic protein-1), while SHLP2 treatment had no such effect [4].

Protection from OS and ER stress: Mitochondria are the main energy-producing organelles, but also the main ROS producer, which causes oxidative damage to proteins, lipids and mtDNA, and is involved in the development of low-grade chronic inflammation, ageing, CVD and premature death $[68,69]$. However, experiments on several cell lines (such as retinal pigment epithelium, lens epithelial cells, cortical neurons and neuroblastoma cancer cells) proved that $\mathrm{HN}$ could protect mitochondria and cells from oxidative stress and ER stress [70-73]. HN acts via a mitochondrial antioxidant defence system, where HN stimulates expression of SOD1 (Superoxide Dismutase 1), biosynthesis and restoring 
the mitochondrial pool of glutathione [72,74]. Both factors (glutathione and SOD1) are known cardioprotectors against ischemia-reperfusion injury and other CVDs [75]. Other research has shown that HN treatment protects retina cells from OS-induced cell death by ameliorating mitochondrial functions (upregulated mtTFA (Mitochondrial transcription factor A) and increased mtDNA copy number), stimulate STAT3 phosphorylation and inhibit caspase-3 activation [76]. The ability of $\mathrm{HN}$ to inhibit the ROS-dependent JNK/p38 MAPK (Janus Kinase/Mitogen-Activated Protein Kinase 14 or P38 MAP Kinase) signalling pathway was also shown in a cortical neurons model [77]. In experiments on human aortic endothelial cells, HN treatment protects from OS via downregulation of NOX2 (SuperoxideGenerating NADPH Oxidase Heavy Chain Subunit) and TxNIP (Thioredoxin Interacting Protein) gene expression and leads to a reduction in ROS and protein carbonyl [65]. NOX2 is the main player in cardiac oxidative damage [78], while TxNIP and protein carbonyl are markers of metabolic and oxidative stress [79,80]. Similarly, protective properties against oxidative stress were shown for HN analogue HNG on SH-SY5Y neuroblastoma cells, where HNG acted via the PI3K/AKT (phosphatidylinositol 3-kinase/protein kinase B) pathway [81], a crucial signalling pathway involved in the regulation of apoptosis, cell differentiation and proliferation [82]. Further details of the HN-mediated protection against OS in CVD could be found in a recent review [83].

Anti-apoptosis properties: Humanin plays an important role in cytoprotection as an anti-apoptosis factor. Several studies have shown that $\mathrm{HN}$ is involved in the interaction with several signalling pathways improving cell survival and preventing cell death: (1) plasma membrane receptors FPRL1 and FPRL2; (2) cytokine-like receptors CNTF (Ciliary Neuronotrophic Factor), IL27RA (Interleukin 27 Receptor Subunit Alpha) and IL6ST (Interleukin 6 Cytokine Family Signal Transducer) to affect the JAK and STAT3 signalling pathways; (3) MAPK14 (Mitogen-Activated Protein Kinase 14) and MAPK3 (MitogenActivated Protein Kinase 3); (4) AMPK; (5) BAX (BCL2 Associated X, Apoptosis Regulator) and BCL2L11 (BCL2-Like 11 Apoptosis Facilitator); (6) IGFBP-3 (insulin-like growth factorbinding protein 3) reviewed in [84]; and (7) inhibiting the membrane association and oligomerization of the apoptosis regulators and mediators of mitochondrial damage Bax and Bid (BH3-Interacting Domain Death Agonist) proteins [85-87]. Similarly, anti-apoptosis properties were shown for SHLP2 and SHLP3, while SHLP6 increased apoptosis [4]. An anti-apoptosis effect was also shown for the Humanin analogue HNG, which was checked on chondrocytes of arthritis and severe combined immunodeficiency mice models $[88,89]$.

However, opposite properties were defined for $\mathrm{HN}$ in cancer cells. It was defined that $H N$ was upregulated in TNBC (triple-negative breast cancer) model biopsies. Application of $\mathrm{HN}$ in a TNBC mice model leads to a reduction in the tumour apoptotic rate, stimulates tumour progression, growth and lung metastases development, thus abating chemotherapy effects [90]. Thereby, HN may have tumour-stimulation activity and a tumour HN-blocking strategy could be considered as a possible target to increase the efficacy of chemotherapy in breast cancer treatment.

In sum, we can conclude that MDPs have a strong connection with the main CVD risk factors (atherosclerosis, hyperlipidaemia, insulin resistance and ageing) and act as anti-apoptosis and anti-inflammation agents, providing protection against ROS and OS (Figure 1). However, current research data are mostly obtained on $\mathrm{HN}$ and its modification, HNG, while the bioactive properties of SHLPs and MOTS-c are less studied and require more attention. The potential tumour-stimulating properties of MDPs and the effect of MDP-silencing tools on the efficacy of chemotherapy should be further studied. 


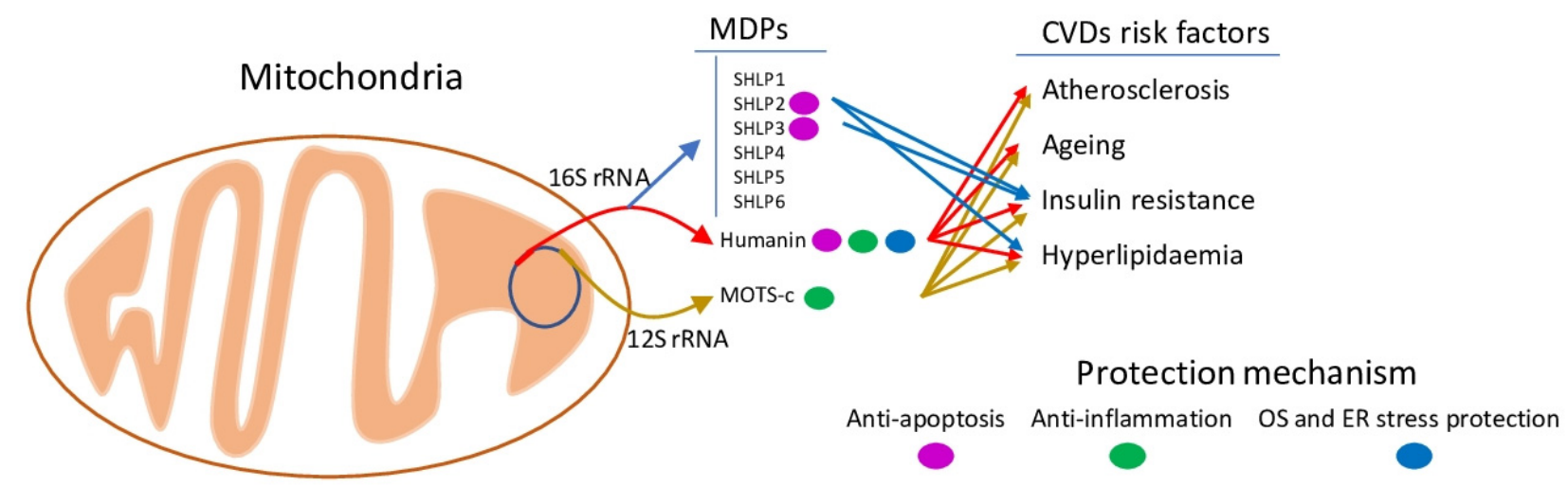

Figure 1. Classification and protection mechanisms of MDPs against CVD risk factors. MDPs (Humanin, SHLPs and MOTS-c) are hidden in mitochondrial $16 \mathrm{~S}$ and 12S rRNA genes. MDPs are associated with CVD risk factors (atherosclerosis, ageing, insulin resistance and hyperlipidaemia). The main cardioprotective activities identified for MDPs are anti-apoptosis and anti-inflammation, offering protection from OS and ER stresses.

\section{Association between MDPs and CVDs}

Coronary microvascular dysfunction: CMD (coronary microvascular dysfunction) refers to functional and structural abnormalities in small coronary vessels. CMD carriers have an increased risk of the development of hypertensive heart disease, heart failure, chronic inflammatory, autoimmune diseases and diabetes; also, it was shown that inflammation and ED (endothelial dysfunction) are the main cause of CMD [91]. The HN level is decreased in CMD patients [92], thus suggesting that the CMD protective properties of $\mathrm{HN}$ are based on anti-inflammation and anti-atherosclerosis activities on ED. These results also suggest $\mathrm{HN}$ as a biomarker of ED and a possible therapeutic target for CMD treatment. Similarly, decreased levels of MOTS-c correlate with ED [42]. However, the exact molecular mechanisms of MDPs on CMD are not known and require further investigation.

Myocardial fibrosis: Myocardial fibrosis refers to histological changes in the myocardium through increased myofibroblast activity and excessive extracellular matrix deposition, identified in several chronic cardiac diseases and eventually leading to heart failure and death [93]. The cardioprotective effect of HNG treatment on myocardial fibrosis and apoptosis was shown on aged mice, where HNG application significantly reduced apoptosis, collagen deposition in aged hearts, cardiac fibroblast proliferation and expression of MMP2 (Matrix Metallopeptidase 2), FGF2 (Fibroblast Growth Factor 2) and TGFB1 (Transforming Growth Factor Beta 1). Mechanically, HNG acts via upregulation of the $A K T$ / GSK3B (Protein kinase B/Glycogen Synthase Kinase 3 $\beta$ ) pathway [94]. Elevated expression of FGF2 and MMP2 in the ageing heart is associated with the promotion of cardiac fibrosis [95]. Mechanically, pGSK-3 $\beta$ relies on the amelioration of mitochondrial function, suppression of ER stress and myocardial apoptosis [96].

Myocardial ischemia and reperfusion injury: AMI (acute myocardial ischemia) is a leading cause of death worldwide. This sudden blockage of cardiac blood vessels leads to decreased or completely stopped blood flow to a part of the heart, causing heart damage or necrosis. PCA (percutaneous coronary angioplasty) treatment could quickly and effectively restore the blood flow in the damaged area and reduce the associated morbidity and complications. However, such blood flow restoration to the ischemic zone causes a significant rise in damaging ROS, called MRI (myocardial reperfusion injury), and is associated with further complications (reperfusion arrhythmias, myocardial stunning and lethal reperfusion) [97,98].

According to published research, MDPs protect the heart in AMI and MRI. Application of HNG during the ischemic period attenuated the heart mitochondrial dysfunction, resulting in increased $\mathrm{HN}$ levels in the damaged myocardium and decreased left ventricular dysfunction, myocardial infarct size and cardiac arrhythmia [99,100]. The OS and ROS cause cardiac mitochondria swelling, depolarization and reduced ATP production. 
These effects were attenuated by HNG treatment, which protects mitochondria through decreased complex I activity [101]. Similarly, HNG protects brain mitochondria during AMI and MRI, reducing tau hyperphosphorylation, $\mathrm{A} \beta$ accumulation and apoptosis $[102,103]$. However, in the porcine model system, the cardioprotective effect of HNG treatment was observed only for short-term ischemia, with no significant protective effect with prolonged ischemia [104]. In this research, the inhibition of apoptosis was suggested as a primarily protective mechanism. Recently, a novel role of HNG in platelet function and thrombus formation was defined [105]. HNG treatment inhibited platelet aggregation, P-selectin expression, $\alpha \mathrm{Ilb} \beta 3$ activation and adhesion under flow conditions. The potential molecular mechanism of microtubule stabilization was suggested as enhanced tubulin acetylation and inhibited microtubule depolymerization [105].

In total, the presented data suggest that MDPs protect the heart and vessels from disease-causing threads by improving mitochondrial functioning, reducing the consequences of OS damage and elevated ROS levels. Anti-inflammation and anti-atherosclerosis effects protect against endothelial dysfunction, while the anti-apoptotic effect is a primary protective mechanism against myocardial ischemia and reperfusion injury.

The discussed connections between CVDs and MDPs are summarized in Table 2.

Table 2. Identified connections between CVDs and MDPs.

\begin{tabular}{|c|c|c|c|}
\hline CVD & MDP & The Way of Action & References \\
\hline \multirow[t]{2}{*}{ CMD } & $\mathrm{HN}$ & $\begin{array}{c}\mathrm{HN} \text { level is decreased in CMD patients; } \mathrm{HN} \text { is a } \\
\text { biomarker of ED }\end{array}$ & [92] \\
\hline & MOTS-c & MOTS-c level correlates with ED & [42] \\
\hline Myocardial fibrosis & HNG & $\begin{array}{l}\text { reduces apoptosis, collagen deposition in aged hearts, } \\
\text { cardiac fibroblast proliferation and expression of } M M P 2, \\
\text { FGF2 and TGFB1; up-regulates } A K T \text { / GSK3B pathway } \\
\text { attenuates the heart mitochondrial dysfunction; decreases }\end{array}$ & [94] \\
\hline \multirow{4}{*}{$\begin{array}{l}\text { Myocardial ischemia and } \\
\text { reperfusion injury }\end{array}$} & & $\begin{array}{c}\text { left ventricular dysfunction, myocardial infarct size and } \\
\text { cardiac arrhythmia }\end{array}$ & {$[99,100]$} \\
\hline & $\mathrm{HNG}$ & $\begin{array}{l}\text { attenuates cardiac mitochondria swelling, depolarization } \\
\text { and reduced ATP production; decreases mitochondrial } \\
\text { complex I activity. }\end{array}$ & [101] \\
\hline & & $\begin{array}{c}\text { protects brain mitochondria during } \mathrm{AMI} \text { and MRI, } \\
\text { reducing tau hyperphosphorylation, } \mathrm{A} \beta \text { accumulation } \\
\text { and apoptosis }\end{array}$ & {$[102,103]$} \\
\hline & & $\begin{array}{c}\text { inhibits platelet aggregation, } P \text {-selectin expression, } \alpha \operatorname{IIb} \beta 3 \\
\text { activation and adhesion under flow conditions; enhances } \\
\text { tubulin acetylation and inhibits microtubule } \\
\text { depolymerization }\end{array}$ & [105] \\
\hline
\end{tabular}

\section{Therapeutic Application of Modified MDPs}

Among all MDPs, $\mathrm{HN}$ is the first identified and better studied, with diverse biological activities in apoptosis, inflammation, cell stress responses and metabolism modification, thus making it an attractive candidate for application as a therapeutic agent. However, as a short peptide, $\mathrm{HN}$ is subjected to rapid tissue clearance, resulting in low availability. Similar to the neuroprotective effect of $\mathrm{HN}$ [2], the neuroprotective properties of the primary $\mathrm{HN}$ modification (HNG (S14G)) were investigated in the original report [1], which has a 1000fold stronger biological activity than unmodified Humanin [81]. While the biological properties of HNG have been widely covered in this manuscript, we further focus on other HN modifications and their therapeutic application.

Recently, the neuroprotective and myoprotective effects were evaluated for the synthetic HN analogues HUJInin (resulted from the conjugation of HN modification (G14) HNG17-NH2 and NAP (an 8-amino-acid neuroprotective peptide NAPVSIPQ, also called davundetide) and cyclic(D-Ser14)AGA-(C8R)humanin [106]. The neuroprotective effect was dose-dependent and relies on improvement of the mitochondrial functions, stimulation 
of AKT phosphorylation and attenuation of insult-induced Erk1/2 (Mitogen-Activated Protein Kinase 1 and 3) phosphorylation. A myoprotective effect was observed towards doxorubicin-induced apoptosis and necrosis cell death insults [106]. Doxorubicin is a crucial anti-cancer and cytotoxic drug, which is used in different chemotherapy protocols for the treatment of lymphoma, breast cancer and leukaemia. However, cardiotoxicity is one of the main life-threatening side effects of doxorubicin treatment, resulting in significant morbidity and mortality in cancer patients [107]. Thus, further improvement of HUJInin and $\mathrm{c}(\mathrm{D}-\mathrm{Ser} 14-\mathrm{HN})$ could lead to the development of new drugs to treat stroke and /or doxorubicin-induced cardiotoxicity in cancer patients. HNG was also effectively used in combination with dexrazoxane, an approved drug against dox-induced cardiotoxicity [108].

Strong neuroprotective properties were shown for the $\mathrm{HN}$ analogue called colivelin (AGA-(C8R)HNG17, attached to the C-terminus of ADNF (activity-dependent neurotrophic factor)).

Experiments on APPswe/PS1dE9 mice (Alzheimer's disease model) suggested that colivelin treatment improve the cognitive and behavioural functions and reduced $A \beta$ deposition in the hippocampus in APP/PS1 mice [109]. Colivelin was also shown to protect neurons after ischemic brain injury. In mice, subjected to $60 \mathrm{~min}$ induction of transient focal cerebral ischemia and reperfusion, colivelin administration activated the STAT3 signalling pathway, inhibited axonal damage and neuronal death in brain tissue, increased axonal growth and decreased the neurological deficits and infarct lesion induced by brain ischemia [110]. Thus, colivelin is a promising drug candidate that could be used as a single or adjunct therapy in Alzheimer's disease and ischemic stroke.

The efficiency of recombinant fusion between HN and thermally responsive ELP (elastin-like polypeptides) against human AMD (age-related macular degeneration) was recently evaluated. Thereby, $\mathrm{HN}$ facilitates cellular delivery of biodegradable nanoparticles, binds human RPE (retinal pigment epithelium) cells and protects against OS-mediated apoptosis [70]. Similarly, the Humanin derivative AGA-HNG (AGA-(CR8)HNG17) encapsulated in chitosan nanoparticles was shown to reduce the inflammatory response characteristic of AMD modulated on ARPE-19 (immortalized retinal pigment epithelial) cells. Nanoencapsulated AGA-HNG significantly decreased apoptosis in hypoxic cells and reduced expression of VEGF (Vascular endothelial growth factor) with reduced cellular toxicity in comparison to the free drug [111]. Currently, anti-VEGF therapy is the most promising treatment in ophthalmology [112], and, because VEGF is produced and acts only locally, the application of nano-encapsulated $\mathrm{HN}$ analogues could provide a valuable drug candidate to reduce the pathogenesis characteristic of AMD with minimum toxic effects to cells.

The application of $\mathrm{HN}$ and its analogues in cancer treatment is a promising area to explore. As it was recently shown, silencing of the HN gene with BV-shHN (Baculovirusencoded short-hairpin RNA) had a cytoprotective effect in pituitary tumour cells. Further, intratumor injection of BV-shHN into nude mice with pituitary adenoma increased the number of apoptotic cells, delayed tumour growth and enhanced their survival rate, suggesting that $\mathrm{HN}$ is involved in pituitary tumour growth and progression and could be a target for therapeutic intervention in the treatment of pituitary tumours [113]. HN also has an inhibitory effect on lung cancer cells growth. The molecular pathway relies on circNOL10 (circular RNA NOL10), which promotes the expression of TF SCML1 (sex comb on midleg-like 1) —one of the regulators of HN expression [114]. Thus, circNOL10 could serve as a novel target for the molecular therapy of lung cancer with HN-mediated improvement of mitochondrial function, inhibition of tumour cell proliferation and cell cycle progression, thereby inhibiting lung cancer development.

Neuroprotection was the first discovered function of HN; however, the presented data suggest that $\mathrm{HN}$ has a wide area of application against other diseases, including different types of cancer. Detailed molecular mechanisms of action and activated pathways are mostly unknown and require further investigation. Recent progress allows to significantly increase the biologic activity of the synthetic $\mathrm{HN}$ analogues, packing it into nanoparticles 
for delivery to the required place of action and silencing $\mathrm{HN}$ in a tissue-specific way, thus extending the therapeutic application of $\mathrm{HN}$.

\title{
5. Conclusions
}

Identified mitochondrial-derived peptides are hidden in mitochondria genes and closely associated with human mitochondria metabolism as well as neurodegenerative and age-related diseases. The main studied activities of MDPs are linked to cytoprotection, which is achieved via amelioration of mitochondrial functions by OS and ER stress protection, and anti-inflammation mechanisms. In this review, we summarized the recent progress in understanding the functions of MDPs in cardioprotection against the main CVD risk factors (atherosclerosis, hyperlipidaemia, ageing and insulin resistance). We could conclude that MDPs could be considered as promising targets in the treatment of CVD, protecting the heart and vascular endothelial cells. However, some MDPs have been assigned with undesirable activities (stimulate the production of pro-inflammatory cytokines, promote tumour growth and decrease the efficacy of chemotherapy); thus, further studies are required to eliminate these activities or minimize their influence. Recent research also suggests the existence of new MDPs encoded by mitochondrial genes and mitochondria-acting micropeptides encoded by the nuclear genome. Modern research techniques, applying nanotechnologies and in vitro peptide synthesis, allow to greatly increase biologic activity and deliver MDPs directly to the place of action, thus further expanding the therapeutic application of MDPs.

Author Contributions: S.A.D., N.G.N. and A.N.O. conceptualized the manuscript; S.A.D. wrote the manuscript text; N.G.N., A.V.S., T.V.P. and A.N.O. reviewed the text; N.G.N. and A.V.S. contributed to the methodology; T.V.P. and A.V.S. contributed to the formal analysis; A.N.O. obtained funding and supervised. All authors have read and agreed to the published version of the manuscript.

Funding: This work was supported by the Russian Science Foundation (Grant \# 20-65-46021).

Institutional Review Board Statement: Not applicable.

Informed Consent Statement: Not applicable.

Data Availability Statement: Not applicable.

Conflicts of Interest: The authors declare no conflict of interest. The funders had no role in the design of the study; in the collection, analyses, or interpretation of data; in the writing of the manuscript, or in the decision to publish the results.

\author{
Abbreviations \\ ABCA1 ATP-binding cassette transporter A1 \\ ABCG1 ATP-binding cassette sub-family G member 1 \\ ACC acetyl CoA carboxylase \\ ADNF activity-dependent neurotrophic factor \\ AhR aryl hydrocarbon receptor \\ AICAR 5-aminoimidazole-4-carboxamide ribonucleotide \\ AKT protein kinase B \\ AMD age-related macular degeneration \\ AMI acute myocardial ischemia \\ AMPK AMP-activated protein kinase \\ ARPE-19 immortalized retinal pigment epithelial \\ AT-1 angiotensin II type 1 \\ av-scO1 avian strongly conserved sORFs 1 \\ BAX BCL2 Associated $X$, apoptosis regulator \\ BCL2L11 BCL2-like 11 apoptosis facilitator \\ Bid BH3-interacting domain death agonist \\ BV-shHN Baculovirus-encoded short-hairpin RNA
}




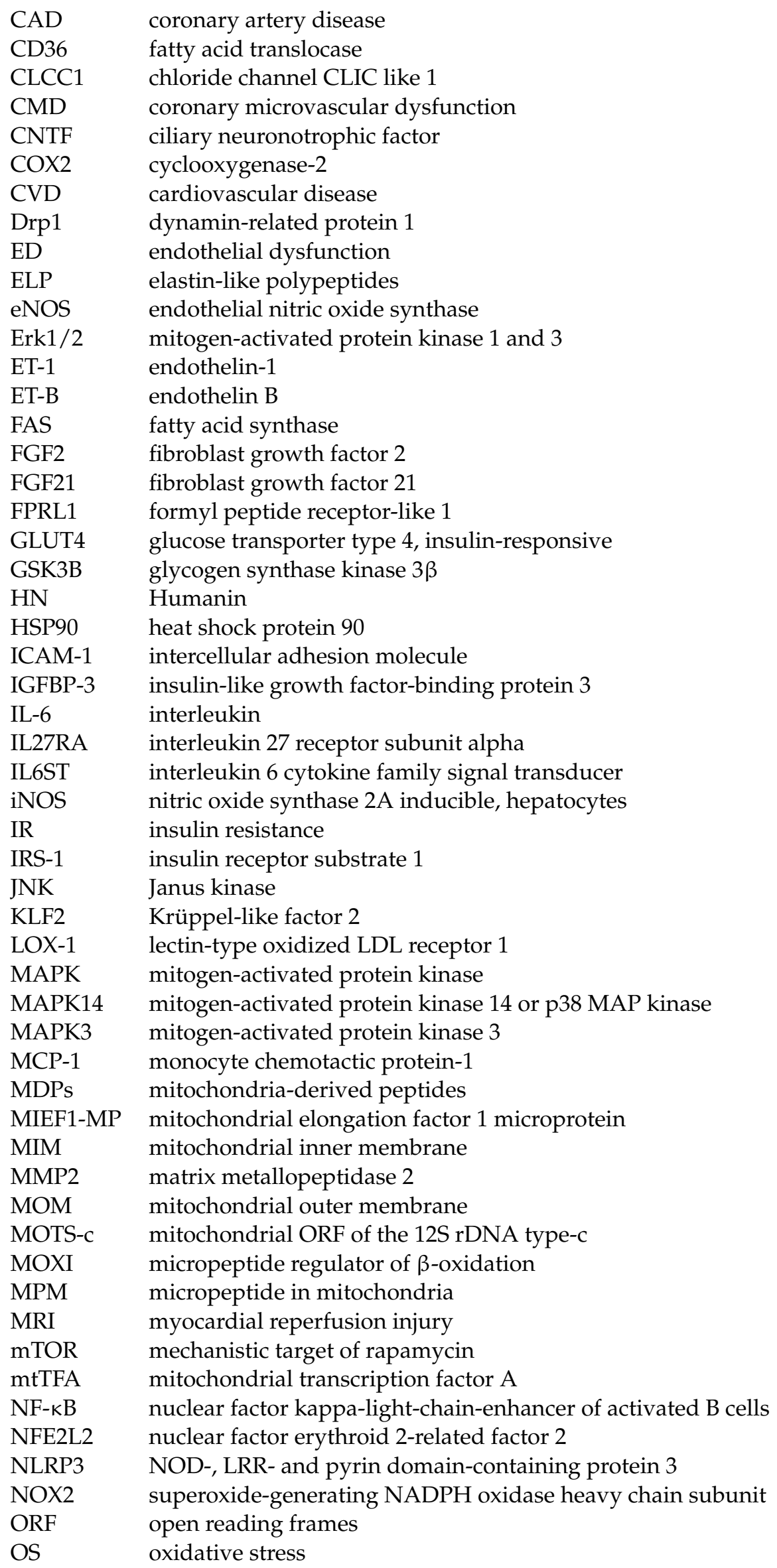




$\begin{array}{ll}\text { Ox-LDL } & \text { oxidized low-density lipoprotein } \\ \text { OXPHOS } & \begin{array}{l}\text { oxidative phosphorylation } \\ \text { percutaneous coronary angioplasty }\end{array} \\ \text { PCA } & \begin{array}{l}\text { peroxisome proliferator-activated receptor gamma coactivator 1-alpha } \\ \text { PGC1 } \alpha\end{array} \\ \text { PI3K } & \text { phosphatidylinositol 3-kinase } \\ \text { ROS } & \text { reactive oxygen species } \\ \text { RPE } & \text { retinal pigment epithelium } \\ \text { SASPs } & \text { senescence-associated secretory phenotypes } \\ \text { SCD1 } & \text { acyl-CoA desaturase } \\ \text { SCML1 } & \text { sex comb on midleg-like 1 } \\ \text { SHLP } & \text { small humanin-like peptide, 1 to } 6 \\ \text { SIRT1 } & \text { Sirtuin 1 } \\ \text { SNPs } & \text { single nucleotide polymorphisms } \\ \text { SOD1 } & \text { superoxide dismutase 1 } \\ \text { SREBP1 } & \text { sterol regulatory element-binding transcription factor 1 } \\ \text { STAT3 } & \text { signal transducer and activator of transcriptional 3 } \\ \text { TGFB1 } & \text { transforming growth factor-beta 1 } \\ \text { TNBC } & \text { triple-negative breast cancer } \\ \text { TNF- } \alpha & \text { tumour necrosis factor-alpha } \\ \text { TxNIP } & \text { thioredoxin interacting protein } \\ \text { UPR } & \text { unfolded protein response } \\ \text { VCAM-1 } & \text { vascular cell adhesion molecule 1 } \\ \text { VEGF } & \text { vascular endothelial growth factor } \\ & \end{array}$

\section{References}

1. Hashimoto, Y.; Niikura, T.; Ito, Y.; Sudo, H.; Hata, M.; Arakawa, E.; Abe, Y.; Kita, Y.; Nishimoto, I. Detailed Characterization of Neuroprotection by a Rescue Factor Humanin against Various Alzheimer's Disease-Relevant Insults. J. Neurosci. 2001, 21, 9235-9245. [CrossRef] [PubMed]

2. Hashimoto, Y.; Niikura, T.; Tajima, H.; Yasukawa, T.; Sudo, H.; Ito, Y.; Kita, Y.; Kawasumi, M.; Kouyama, K.; Doyu, M.; et al. A Rescue Factor Abolishing Neuronal Cell Death by a Wide Spectrum of Familial Alzheimer's Disease Genes and A. Proc. Natl. Acad. Sci. USA 2001, 98, 6336-6341. [CrossRef]

3. Lee, C.; Zeng, J.; Drew, B.G.; Sallam, T.; Martin-Montalvo, A.; Wan, J.; Kim, S.-J.; Mehta, H.; Hevener, A.L.; de Cabo, R.; et al. The Mitochondrial-Derived Peptide MOTS-c Promotes Metabolic Homeostasis and Reduces Obesity and Insulin Resistance. Cell Metab. 2015, 21, 443-454. [CrossRef] [PubMed]

4. Cobb, L.J.; Lee, C.; Xiao, J.; Yen, K.; Wong, R.G.; Nakamura, H.K.; Mehta, H.H.; Gao, Q.; Ashur, C.; Huffman, D.M.; et al. Naturally Occurring Mitochondrial-Derived Peptides Are Age-Dependent Regulators of Apoptosis, Insulin Sensitivity, and Inflammatory Markers. Aging 2016, 8, 796-809. [CrossRef]

5. Merry, T.L.; Chan, A.; Woodhead, J.S.T.; Reynolds, J.C.; Kumagai, H.; Kim, S.-J.; Lee, C. Mitochondrial-Derived Peptides in Energy Metabolism. Am. J. Physiol. Endocrinol. Metab. 2020, 319, E659-E666. [CrossRef]

6. Sreekumar, P.G.; Kannan, R. Mechanisms of Protection of Retinal Pigment Epithelial Cells from Oxidant Injury by Humanin and Other Mitochondrial-Derived Peptides: Implications for Age-Related Macular Degeneration. Redox Biol. 2020, $37,101663$. [CrossRef] [PubMed]

7. Zuccato, C.F.; Asad, A.S.; Nicola Candia, A.J.; Gottardo, M.F.; Moreno Ayala, M.A.; Theas, M.S.; Seilicovich, A.; Candolfi, M. Mitochondrial-Derived Peptide Humanin as Therapeutic Target in Cancer and Degenerative Diseases. Expert Opin. Ther. Targets 2019, 23, 117-126. [CrossRef] [PubMed]

8. Mendelsohn, A.R.; Larrick, J.W. Mitochondrial-Derived Peptides Exacerbate Senescence. Rejuvenation Res. 2018, 21, 369-373. [CrossRef]

9. $\quad$ Rao, M.; Wu, Z.; Wen, Y.; Wang, R.; Zhao, S.; Tang, L. Humanin Levels in Human Seminal Plasma and Spermatozoa Are Related to Sperm Quality. Andrology 2019, 7, 859-866. [CrossRef] [PubMed]

10. Rodriguez Paris, V.; Walters, K.A. Humanin: A Potential Treatment for PCOS? Endocrinology 2021, 162, bqab085. [CrossRef] [PubMed]

11. Boguszewska, K.; Szewczuk, M.; Kaźmierczak-Barańska, J.; Karwowski, B.T. The Similarities between Human Mitochondria and Bacteria in the Context of Structure, Genome, and Base Excision Repair System. Molecules 2020, 25, 2857. [CrossRef] [PubMed]

12. Vizioli, M.G.; Liu, T.; Miller, K.N.; Robertson, N.A.; Gilroy, K.; Lagnado, A.B.; Perez-Garcia, A.; Kiourtis, C.; Dasgupta, N.; Lei, X.; et al. Mitochondria-to-Nucleus Retrograde Signaling Drives Formation of Cytoplasmic Chromatin and Inflammation in Senescence. Genes Dev. 2020, 34, 428-445. [CrossRef] 
13. Gong, Z.; Tasset, I.; Diaz, A.; Anguiano, J.; Tas, E.; Cui, L.; Kuliawat, R.; Liu, H.; Kühn, B.; Cuervo, A.M.; et al. Humanin Is an Endogenous Activator of Chaperone-Mediated Autophagy. J. Cell Biol. 2018, 217, 635-647. [CrossRef]

14. Gong, Z.; Tasset, I. Humanin Enhances the Cellular Response to Stress by Activation of Chaperone-Mediated Autophagy. Oncotarget 2018, 9, 10832-10833. [CrossRef]

15. Qin, Q.; Jin, J.; He, F.; Zheng, Y.; Li, T.; Zhang, Y.; He, J. Humanin Promotes Mitochondrial Biogenesis in Pancreatic MIN6 $\beta$-Cells. Biochem. Biophys. Res. Commun. 2018, 497, 292-297. [CrossRef] [PubMed]

16. Logan, I.S. Pseudogenization of the Humanin gene is common in the mitochondrial DNA of many vertebrates. Zool. Res. 2017, 38, 198-202. [CrossRef] [PubMed]

17. Kim, J.; Choi, J.-W.; Namkung, J. Expression Profile of Mouse Gm20594, Nuclear-Encoded Humanin-Like Gene. J. Lifestyle Med. 2021, 11, 13-22. [CrossRef] [PubMed]

18. Mortz, M.; Dégletagne, C.; Romestaing, C.; Duchamp, C. Comparative Genomic Analysis Identifies Small Open Reading Frames (SORFs) with Peptide-Encoding Features in Avian 16S RDNA. Genomics 2020, 112, 1120-1127. [CrossRef]

19. Capt, C.; Passamonti, M.; Breton, S. The Human Mitochondrial Genome May Code for More than 13 Proteins. Mitochondrial DNA Part A 2016, 27, 3098-3101. [CrossRef] [PubMed]

20. Li, H.; Ren, K.; Jiang, T.; Zhao, G.-J. MOTS-c Attenuates Endothelial Dysfunction via Suppressing the MAPK/NF-KB Pathway. Int. J. Cardiol. 2018, 268, 40. [CrossRef] [PubMed]

21. Kim, K.H.; Son, J.M.; Benayoun, B.A.; Lee, C. The Mitochondrial-Encoded Peptide MOTS-c Translocates to the Nucleus to Regulate Nuclear Gene Expression in Response to Metabolic Stress. Cell Metab. 2018, 28, 516-524. [CrossRef]

22. Reynolds, J.C.; Lai, R.W.; Woodhead, J.S.T.; Joly, J.H.; Mitchell, C.J.; Cameron-Smith, D.; Lu, R.; Cohen, P.; Graham, N.A.; Benayoun, B.A.; et al. MOTS-c Is an Exercise-Induced Mitochondrial-Encoded Regulator of Age-Dependent Physical Decline and Muscle Homeostasis. Nat. Commun. 2021, 12, 470. [CrossRef]

23. Okada, A.K.; Teranishi, K.; Lobo, F.; Isas, J.M.; Xiao, J.; Yen, K.; Cohen, P.; Langen, R. The Mitochondrial-Derived Peptides, HumaninS14G and Small Humanin-like Peptide 2, Exhibit Chaperone-like Activity. Sci. Rep. 2017, 7, 7802. [CrossRef]

24. Nashine, S.; Cohen, P.; Nesburn, A.B.; Kuppermann, B.D.; Kenney, M.C. Characterizing the Protective Effects of SHLP2, a Mitochondrial-Derived Peptide, in Macular Degeneration. Sci. Rep. 2018, 8, 15175. [CrossRef]

25. Chu, Q.; Martinez, T.F.; Novak, S.W.; Donaldson, C.J.; Tan, D.; Vaughan, J.M.; Chang, T.; Diedrich, J.K.; Andrade, L.; Kim, A.; et al. Regulation of the ER Stress Response by a Mitochondrial Microprotein. Nat. Commun. 2019, 10, 4883. [CrossRef] [PubMed]

26. Rathore, A.; Chu, Q.; Tan, D.; Martinez, T.F.; Donaldson, C.J.; Diedrich, J.K.; Yates, J.R.; Saghatelian, A. MIEF1 Microprotein Regulates Mitochondrial Translation. Biochemistry 2018, 57, 5564-5575. [CrossRef]

27. Stein, C.S.; Jadiya, P.; Zhang, X.; McLendon, J.M.; Abouassaly, G.M.; Witmer, N.H.; Anderson, E.J.; Elrod, J.W.; Boudreau, R.L. Mitoregulin: A LncRNA-Encoded Microprotein That Supports Mitochondrial Supercomplexes and Respiratory Efficiency. Cell Rep. 2018, 23, 3710-3720.e8. [CrossRef]

28. Lin, Y.-F.; Xiao, M.-H.; Chen, H.-X.; Meng, Y.; Zhao, N.; Yang, L.; Tang, H.; Wang, J.-L.; Liu, X.; Zhu, Y.; et al. A Novel Mitochondrial Micropeptide MPM Enhances Mitochondrial Respiratory Activity and Promotes Myogenic Differentiation. Cell Death Dis. 2019, 10, 528. [CrossRef] [PubMed]

29. Makarewich, C.A.; Baskin, K.K.; Munir, A.Z.; Bezprozvannaya, S.; Sharma, G.; Khemtong, C.; Shah, A.M.; McAnally, J.R.; Malloy, C.R.; Szweda, L.I.; et al. MOXI Is a Mitochondrial Micropeptide That Enhances Fatty Acid $\beta$-Oxidation. Cell Rep. 2018, 23 , 3701-3709. [CrossRef] [PubMed]

30. Karu, I.; Tahepold, P.; Ruusalepp, A.; Reimann, E.; Koks, S.; Starkopf, J. Exposure to Sixty Minutes of Hyperoxia Upregulates Myocardial Humanins in Patients with Coronary Artery Disease-A Pilot Study. J. Physiol Pharm. 2015, 66, 899-906.

31. Eltermaa, M.; Jakobson, M.; Utt, M.; Kõks, S.; Mägi, R.; Starkopf, J. Genetic Variants in Humanin Nuclear Isoform Gene Regions Show No Association with Coronary Artery Disease. BMC Res. Notes 2019, 12, 759. [CrossRef]

32. Zhu, Y.; Xian, X.; Wang, Z.; Bi, Y.; Chen, Q.; Han, X.; Tang, D.; Chen, R. Research Progress on the Relationship between Atherosclerosis and Inflammation. Biomolecules 2018, 8, 80. [CrossRef] [PubMed]

33. Frambach, S.J.C.M.; de Haas, R.; Smeitink, J.A.M.; Rongen, G.A.; Russel, F.G.M.; Schirris, T.J.J. Brothers in Arms: ABCA1- and ABCG1-Mediated Cholesterol Efflux as Promising Targets in Cardiovascular Disease Treatment. Pharm. Rev. 2020, 72, 152-190. [CrossRef]

34. Zhu, W.; Wang, S.; Liu, Z.; Cao, Y.; Wang, F.; Wang, J.; Liu, C.; Xie, Y.; Xie, Y.; Zhang, Y. Gly[14]-Humanin Inhibits Ox-LDL Uptake and Stimulates Cholesterol Efflux in Macrophage-Derived Foam Cells. Biochem. Biophys. Res. Commun. 2017, 482, 93-99. [CrossRef]

35. Ding, Y.; Feng, Y.; Zhu, W.; Zou, Y.; Xie, Y.; Wang, F.; Liu, C.; Zhang, Y.; Liu, H. [Gly14]-Humanin Prevents Lipid Deposition and Endothelial Cell Apoptosis in a Lectin-like Oxidized Low-density Lipoprotein Receptor-1-Dependent Manner. Lipids 2019, 54, 697-705. [CrossRef]

36. Ding, Y.; Feng, Y.; Zou, Y.; Wang, F.; Liu, H.; Liu, C.; Zhang, Y. [Gly14]-Humanin Restores Cathepsin D Function via FPRL1 and Promotes Autophagic Degradation of Ox-LDL in HUVECs. Nutr. Metab. Cardiovasc. Dis. 2020, 30, 2406-2416. [CrossRef]

37. Yuan, T.; Yang, T.; Chen, H.; Fu, D.; Hu, Y.; Wang, J.; Yuan, Q.; Yu, H.; Xu, W.; Xie, X. New Insights into Oxidative Stress and Inflammation during Diabetes Mellitus-Accelerated Atherosclerosis. Redox Biol. 2019, 20, 247-260. [CrossRef] [PubMed]

38. Jha, P.; Das, H. KLF2 in Regulation of NF-KB-Mediated Immune Cell Function and Inflammation. Int. J. Mol. Sci. 2017, 18, 2383. [CrossRef] [PubMed] 
39. Wang, X.; Wu, Z.; He, Y.; Zhang, H.; Tian, L.; Zheng, C.; Shang, T.; Zhu, Q.; Li, D.; He, Y. Humanin Prevents High Glucose-Induced Monocyte Adhesion to Endothelial Cells by Targeting KLF2. Mol. Immunol. 2018, 101, 245-250. [CrossRef]

40. Wei, M.; Gan, L.; Liu, Z.; Liu, L.; Chang, J.-R.; Yin, D.-C.; Cao, H.-L.; Su, X.-L.; Smith, W.W. Mitochondrial-Derived Peptide MOTS-c Attenuates Vascular Calcification and Secondary Myocardial Remodeling via Adenosine Monophosphate-Activated Protein Kinase Signaling Pathway. Cardiorenal Med. 2020, 10, 42-50. [CrossRef]

41. Singh, K.D.; Karnik, S.S. Angiotensin Type 1 Receptor Blockers in Heart Failure. Curr. Drug Targets 2020, 21, 125-131. [CrossRef] [PubMed]

42. Qin, Q.; Delrio, S.; Wan, J.; Jay Widmer, R.; Cohen, P.; Lerman, L.O.; Lerman, A. Downregulation of Circulating MOTS-c Levels in Patients with Coronary Endothelial Dysfunction. Int. J. Cardiol. 2018, 254, 23-27. [CrossRef] [PubMed]

43. Ikonomidis, I.; Katogiannis, K.; Kyriakou, E.; Taichert, M.; Katsimaglis, G.; Tsoumani, M.; Andreadou, I.; Maratou, E.; Lambadiari, V.; Kousathana, F.; et al. $\beta$-Amyloid and Mitochondrial-Derived Peptide-c Are Additive Predictors of Adverse Outcome to High-on-Treatment Platelet Reactivity in Type 2 Diabetics with Revascularized Coronary Artery Disease. J. Thromb. Thrombolysis 2020, 49, 365-376. [CrossRef] [PubMed]

44. Kim, S.-J.; Miller, B.; Kumagai, H.; Silverstein, A.R.; Flores, M.; Yen, K. Mitochondrial-Derived Peptides in Aging and Age-Related Diseases. GeroScience 2021, 43, 1113-1121. [CrossRef]

45. Reynolds, J.C.; Bwiza, C.P.; Lee, C. Mitonuclear Genomics and Aging. Hum. Genet. 2020, 139, 381-399. [CrossRef]

46. Kim, S.-J.; Mehta, H.H.; Wan, J.; Kuehnemann, C.; Chen, J.; Hu, J.-F.; Hoffman, A.R.; Cohen, P. Mitochondrial Peptides Modulate Mitochondrial Function during Cellular Senescence. Aging 2018, 10, 1239-1256. [CrossRef]

47. Conte, M.; Ostan, R.; Fabbri, C.; Santoro, A.; Guidarelli, G.; Vitale, G.; Mari, D.; Sevini, F.; Capri, M.; Sandri, M.; et al. Human Aging and Longevity Are Characterized by High Levels of Mitokines. J. Gerontol. Ser. A 2019, 74, 600-607. [CrossRef]

48. Conte, M.; Sabbatinelli, J.; Chiariello, A.; Martucci, M.; Santoro, A.; Monti, D.; Arcaro, M.; Galimberti, D.; Scarpini, E.; Bonfigli, A.R.; et al. Disease-Specific Plasma Levels of Mitokines FGF21, GDF15, and Humanin in Type II Diabetes and Alzheimer's Disease in Comparison with Healthy Aging. GeroScience 2021, 43, 985-1001. [CrossRef]

49. Huang, T.-Y.; Zheng, D.; Houmard, J.A.; Brault, J.J.; Hickner, R.C.; Cortright, R.N. Overexpression of PGC-1 $\alpha$ Increases Peroxisomal Activity and Mitochondrial Fatty Acid Oxidation in Human Primary Myotubes. Am. J. Physiol. Endocrinol. Metab. 2017, 312, E253-E263. [CrossRef]

50. Römer, A.; Linn, T.; Petry, S.F. Lipotoxic Impairment of Mitochondrial Function in $\beta$-Cells: A Review. Antioxidants 2021, 10, 293. [CrossRef]

51. Gidlund, E.-K.; von Walden, F.; Venojärvi, M.; Risérus, U.; Heinonen, O.J.; Norrbom, J.; Sundberg, C.J. Humanin Skeletal Muscle Protein Levels Increase after Resistance Training in Men with Impaired Glucose Metabolism. Physiol. Rep. 2016, 4, e13063. [CrossRef] [PubMed]

52. Ramanjaneya, M.; Bettahi, I.; Jerobin, J.; Chandra, P.; Abi Khalil, C.; Skarulis, M.; Atkin, S.L.; Abou-Samra, A.-B. MitochondrialDerived Peptides Are Down Regulated in Diabetes Subjects. Front. Endocrinol. 2019, 10, 331. [CrossRef]

53. Han, K.; Jia, N.; Zhong, Y.; Shang, X. S14G-humanin Alleviates Insulin Resistance and Increases Autophagy in Neurons of APP/PS1 Transgenic Mouse. J. Cell. Biochem. 2018, 119, 3111-3117. [CrossRef] [PubMed]

54. Kim, S.-J.; Miller, B.; Kumagai, H.; Yen, K.; Cohen, P. MOTS-c: An Equal Opportunity Insulin Sensitizer. J. Mol. Med. 2019, 97, 487-490. [CrossRef]

55. Kim, S.; Miller, B.; Mehta, H.H.; Xiao, J.; Wan, J.; Arpawong, T.E.; Yen, K.; Cohen, P. The Mitochondrial-derived Peptide MOTS-c Is a Regulator of Plasma Metabolites and Enhances Insulin Sensitivity. Physiol. Rep. 2019, 7, e14171. [CrossRef]

56. Kwon, C.; Sun, J.L.; Jeong, J.H.; Jung, T.W. Humanin Attenuates Palmitate-Induced Hepatic Lipid Accumulation and Insulin Resistance via AMPK-Mediated Suppression of the MTOR Pathway. Biochem. Biophys. Res. Commun. 2020, 526, 539-545. [CrossRef]

57. Magaway, C.; Kim, E.; Jacinto, E. Targeting MTOR and Metabolism in Cancer: Lessons and Innovations. Cells 2019, 8, 1584. [CrossRef]

58. Gong, Z.; Su, K.; Cui, L.; Tas, E.; Zhang, T.; Dong, H.H.; Yakar, S.; Muzumdar, R.H. Central Effects of Humanin on Hepatic Triglyceride Secretion. Am. J. Physiol. Endocrinol. Metab. 2015, 309, E283-E292. [CrossRef] [PubMed]

59. Mehta, H.H.; Xiao, J.; Ramirez, R.; Miller, B.; Kim, S.-J.; Cohen, P.; Yen, K. Metabolomic Profile of Diet-Induced Obesity Mice in Response to Humanin and Small Humanin-like Peptide 2 Treatment. Metabolomics 2019, 15, 88. [CrossRef]

60. Yang, B.; Yu, Q.; Chang, B.; Guo, Q.; Xu, S.; Yi, X.; Cao, S. MOTS-c Interacts Synergistically with Exercise Intervention to Regulate PGC-1 $\alpha$ Expression, Attenuate Insulin Resistance and Enhance Glucose Metabolism in Mice via AMPK Signaling Pathway. Biochim. Biophys. Acta BBA Mol. Basis Dis. 2021, 1867, 166126. [CrossRef] [PubMed]

61. Li, Q.; Lu, H.; Hu, G.; Ye, Z.; Zhai, D.; Yan, Z.; Wang, L.; Xiang, A.; Lu, Z. Earlier Changes in Mice after D-Galactose Treatment Were Improved by Mitochondria Derived Small Peptide MOTS-c. Biochem. Biophys. Res. Commun. 2019, 513, 439-445. [CrossRef]

62. Zhai, D.; Ye, Z.; Jiang, Y.; Xu, C.; Ruan, B.; Yang, Y.; Lei, X.; Xiang, A.; Lu, H.; Zhu, Z.; et al. MOTS-c Peptide Increases Survival and Decreases Bacterial Load in Mice Infected with MRSA. Mol. Immunol. 2017, 92, 151-160. [CrossRef]

63. Lei, W.; Liu, D.; Sun, M.; Lu, C.; Yang, W.; Wang, C.; Cheng, Y.; Zhang, M.; Shen, M.; Yang, Z.; et al. Targeting STAT3: A Crucial Modulator of Sepsis. J. Cell Physiol. 2021. [CrossRef] [PubMed]

64. Bock, K.W. Aryl Hydrocarbon Receptor (AHR)-Mediated Inflammation and Resolution: Non-Genomic and Genomic Signaling. Biochem. Pharmacol. 2020, 182, 114220. [CrossRef] [PubMed] 
65. Li, W.; Zhang, D.; Yuan, W.; Wang, C.; Huang, Q.; Luo, J. Humanin Ameliorates Free Fatty Acid-Induced Endothelial Inflammation by Suppressing the NLRP3 Inflammasome. ACS Omega 2020, 5, 22039-22045. [CrossRef]

66. Stitham, J.; Rodriguez-Velez, A.; Zhang, X.; Jeong, S.-J.; Razani, B. Inflammasomes: A Preclinical Assessment of Targeting in Atherosclerosis. Expert Opin. Ther. Targets 2020, 24, 825-844. [CrossRef]

67. Hemenway, G.; Frishman, W.H. Therapeutic Implications of NLRP3-Mediated Inflammation in Coronary Artery Disease. Cardiol. Rev. 2021. [CrossRef] [PubMed]

68. McGuire, P.J. Mitochondrial Dysfunction and the Aging Immune System. Biology 2019, 8, 26. [CrossRef]

69. Soysal, P.; Arik, F.; Smith, L.; Jackson, S.E.; Isik, A.T. Inflammation, Frailty and Cardiovascular Disease. In Frailty and Cardiovascular Diseases; Veronese, N., Ed.; Advances in Experimental Medicine and Biology; Springer International Publishing: Cham, Switzerland, 2020; Volume 1216, pp. 55-64, ISBN 978-3-030-33329-4.

70. Li, Z.; Sreekumar, P.G.; Peddi, S.; Hinton, D.R.; Kannan, R.; MacKay, J.A. The Humanin Peptide Mediates ELP Nanoassembly and Protects Human Retinal Pigment Epithelial Cells from Oxidative Stress. Nanomed. Nanotechnol. Biol. Med. 2020, $24,102111$. [CrossRef] [PubMed]

71. Yang, H.; Cui, Y.; Tang, Y.; Tang, X.; Yu, X.; Zhou, J.; Yin, Q.; Shentu, X. Cytoprotective Role of Humanin in Lens Epithelial Cell Oxidative Stress-induced Injury. Mol. Med. Rep. 2020, 22, 1467-1479. [CrossRef]

72. Zhao, J.; Zeng, Y.; Wang, Y.; Shi, J.; Zhao, W.; Wu, B.; Du, H. Humanin Protects Cortical Neurons from Calyculin A-Induced Neurotoxicities by Increasing PP2A Activity and SOD. Int. J. Neurosci. 2021, 131, 527-535. [CrossRef]

73. Gurunathan, S.; Jeyaraj, M.; Kang, M.H.; Kim, J.H. Mitochondrial Peptide Humanin Protects Silver Nanoparticles-Induced Neurotoxicity in Human Neuroblastoma Cancer Cells (SH-SY5Y). Int. J. Mol. Sci. 2019, 20, 4439. [CrossRef]

74. Matsunaga, D.; Sreekumar, P.G.; Ishikawa, K.; Terasaki, H.; Barron, E.; Cohen, P.; Kannan, R.; Hinton, D.R. Humanin Protects RPE Cells from Endoplasmic Reticulum Stress-Induced Apoptosis by Upregulation of Mitochondrial Glutathione. PLoS ONE 2016, 11, e0165150. [CrossRef]

75. Dubois-Deruy, E.; Peugnet, V.; Turkieh, A.; Pinet, F. Oxidative Stress in Cardiovascular Diseases. Antioxidants 2020, 9, 864. [CrossRef] [PubMed]

76. Sreekumar, P.G.; Ishikawa, K.; Spee, C.; Mehta, H.H.; Wan, J.; Yen, K.; Cohen, P.; Kannan, R.; Hinton, D.R. The MitochondrialDerived Peptide Humanin Protects RPE Cells From Oxidative Stress, Senescence, and Mitochondrial Dysfunction. Investig. Ophthalmol. Vis. Sci. 2016, 57, 1238. [CrossRef] [PubMed]

77. Yang, X.; Zhang, H.; Wu, J.; Yin, L.; Yan, L.-J.; Zhang, C. Humanin Attenuates NMDA-Induced Excitotoxicity by Inhibiting ROS-Dependent JNK/P38 MAPK Pathway. Int. J. Mol. Sci. 2018, 19, 2982. [CrossRef]

78. Bhatti, S.N.; Li, J.-M. Nox2 Dependent Redox-Regulation of Akt and ERK1/2 to Promote Left Ventricular Hypertrophy in Dietary Obesity of Mice. Biochem. Biophys. Res. Commun. 2020, 528, 506-513. [CrossRef]

79. Domingues, A.; Jolibois, J.; Marquet de Rougé, P.; Nivet-Antoine, V. The Emerging Role of TXNIP in Ischemic and Cardiovascular Diseases; A Novel Marker and Therapeutic Target. Int. J. Mol. Sci. 2021, 22, 1693. [CrossRef]

80. Akyildiz, A.G.; Boran, T.; Jannuzzi, A.T.; Alpertunga, B. Mitochondrial Dynamics Imbalance and Mitochondrial Dysfunction Contribute to the Molecular Cardiotoxic Effects of Lenvatinib. Toxicol. Appl. Pharmacol. 2021, 423, 115577. [CrossRef] [PubMed]

81. Gao, G.-S.; Li, Y.; Zhai, H.; Bi, J.-W.; Zhang, F.-S.; Zhang, X.-Y.; Fan, S.-H. Humanin Analogue, S14G-Humanin, Has Neuroprotective Effects against Oxygen Glucose Deprivation/Reoxygenation by Reactivating Jak2/Stat3 Signaling through the PI3K/AKT Pathway. Exp. Ther. Med. 2017, 14, 3926-3934. [CrossRef]

82. Song, H.-P.; Chu, Z.-G.; Zhang, D.-X.; Dang, Y.-M.; Zhang, Q. PI3K-AKT Pathway Protects Cardiomyocytes against HypoxiaInduced Apoptosis by MitoKATP-Mediated Mitochondrial Translocation of PAKT. Cell Physiol. Biochem. 2018, 49, 717-727. [CrossRef]

83. Cai, H.; Liu, Y.; Men, H.; Zheng, Y. Protective Mechanism of Humanin Against Oxidative Stress in Aging-Related Cardiovascular Diseases. Front. Endocrinol. 2021, 12, 683151. [CrossRef] [PubMed]

84. Hazafa, A.; Batool, A.; Ahmad, S.; Amjad, M.; Chaudhry, S.N.; Asad, J.; Ghuman, H.F.; Khan, H.M.; Naeem, M.; Ghani, U. Humanin: A Mitochondrial-Derived Peptide in the Treatment of Apoptosis-Related Diseases. Life Sci. 2021, $264,118679$. [CrossRef]

85. Ma, Z.; Liu, D. Humanin Decreases Mitochondrial Membrane Permeability by Inhibiting the Membrane Association and Oligomerization of Bax and Bid Proteins. Acta Pharm. Sin. 2018, 39, 1012-1021. [CrossRef] [PubMed]

86. Morris, D.L.; Kastner, D.W.; Johnson, S.; Strub, M.-P.; He, Y.; Bleck, C.K.E.; Lee, D.-Y.; Tjandra, N. Humanin Induces Conformational Changes in the Apoptosis Regulator BAX and Sequesters It into Fibers, Preventing Mitochondrial Outer-Membrane Permeabilization. J. Biol. Chem. 2019, 294, 19055-19065. [CrossRef] [PubMed]

87. Morris, D.L.; Johnson, S.; Bleck, C.K.E.; Lee, D.-Y.; Tjandra, N. Humanin Selectively Prevents the Activation of Pro-Apoptotic Protein BID by Sequestering It into Fibers. J. Biol. Chem. 2020, 295, 18226-18238. [CrossRef]

88. Celvin, B.; Zaman, F.; Aulin, C.; Sävendahl, L. Humanin Prevents Undesired Apoptosis of Chondrocytes without Interfering with the Anti-Inflammatory Effect of Dexamethasone in Collagen-Induced Arthritis. Clin. Exp. Rheumatol. 2020, 38, $129-135$.

89. Jia, Y.; Lue, Y.; Swerdloff, R.S.; Lasky, J.L.; Panosyan, E.H.; Dai-Ju, J.; Wang, C. The Humanin Analogue (HNG) Prevents Temozolomide-Induced Male Germ Cell Apoptosis and Other Adverse Effects in Severe Combined Immuno-Deficiency (SCID) Mice Bearing Human Medulloblastoma. Exp. Mol. Pathol. 2019, 109, 42-50. [CrossRef] 
90. Ayala, M.A.M.; Gottardo, M.F.; Zuccato, C.F.; Pidre, M.L.; Nicola Candia, A.J.; Asad, A.S.; Imsen, M.; Romanowski, V.; Creton, A.; Isla Larrain, M.; et al. Humanin Promotes Tumor Progression in Experimental Triple Negative Breast Cancer. Sci. Rep. 2020, 10, 8542. [CrossRef] [PubMed]

91. Vancheri, F.; Longo, G.; Vancheri, S.; Henein, M. Coronary Microvascular Dysfunction. J. Clin. Med. 2020, 9, 2880. [CrossRef] [PubMed]

92. Widmer, R.J.; Flammer, A.J.; Herrmann, J.; Rodriguez-Porcel, M.; Wan, J.; Cohen, P.; Lerman, L.O.; Lerman, A. Circulating Humanin Levels Are Associated with Preserved Coronary Endothelial Function. Am. J. Physiol. Heart Circ. Physiol. 2013, 304, H393-H397. [CrossRef] [PubMed]

93. López, B.; Ravassa, S.; Moreno, M.U.; José, G.S.; Beaumont, J.; González, A.; Díez, J. Diffuse Myocardial Fibrosis: Mechanisms, Diagnosis and Therapeutic Approaches. Nat. Rev. Cardiol. 2021, 18, 479-498. [CrossRef]

94. Qin, Q.; Mehta, H.; Yen, K.; Navarrete, G.; Brandhorst, S.; Wan, J.; Delrio, S.; Zhang, X.; Lerman, L.O.; Cohen, P.; et al. Chronic Treatment with the Mitochondrial Peptide Humanin Prevents Age-Related Myocardial Fibrosis in Mice. Am. J. Physiol. Heart Circ. Physiol. 2018, 315, H1127-H1136. [CrossRef]

95. Liguori, T.T.A.; Liguori, G.R.; Moreira, L.F.P.; Harmsen, M.C. Fibroblast Growth Factor-2, but Not the Adipose Tissue-Derived Stromal Cells Secretome, Inhibits TGF-B1-Induced Differentiation of Human Cardiac Fibroblasts into Myofibroblasts. Sci. Rep. 2018, 8, 16633. [CrossRef]

96. Wang, Y.; Ge, C.; Chen, J.; Tang, K.; Liu, J. GSK-3 $\beta$ Inhibition Confers Cardioprotection Associated with the Restoration of Mitochondrial Function and Suppression of Endoplasmic Reticulum Stress in Sevoflurane Preconditioned Rats Following Ischemia/Reperfusion Injury. Perfusion 2018, 33, 679-686. [CrossRef] [PubMed]

97. González-Montero, J.; Brito, R.; Gajardo, A.I.; Rodrigo, R. Myocardial Reperfusion Injury and Oxidative Stress: Therapeutic Opportunities. World J. Cardiol. 2018, 10, 74-86. [CrossRef]

98. Arrigo, M.; Price, S.; Baran, D.A.; Pöss, J.; Aissaoui, N.; Bayes-Genis, A.; Bonello, L.; François, B.; Gayat, E.; Gilard, M.; et al. Optimising Clinical Trials in Acute Myocardial Infarction Complicated by Cardiogenic Shock: A Statement from the 2020 Critical Care Clinical Trialists Workshop. Lancet Respir. Med. 2021. [CrossRef]

99. Thummasorn, S.; Shinlapawittayatorn, K.; Chattipakorn, S.C.; Chattipakorn, N. High-Dose Humanin Analogue Applied during Ischemia Exerts Cardioprotection against Ischemia/Reperfusion Injury by Reducing Mitochondrial Dysfunction. Cardiovasc. Ther. 2017, 35, e12289. [CrossRef]

100. Thummasorn, S.; Apaijai, N.; Kerdphoo, S.; Shinlapawittayatorn, K.; Chattipakorn, S.C.; Chattipakorn, N. Humanin Exerts Cardioprotection against Cardiac Ischemia/Reperfusion Injury through Attenuation of Mitochondrial Dysfunction. Cardiovasc. Ther. 2016, 34, 404-414. [CrossRef]

101. Thummasorn, S.; Shinlapawittayatorn, K.; Khamseekaew, J.; Jaiwongkam, T.; Chattipakorn, S.C.; Chattipakorn, N. Humanin Directly Protects Cardiac Mitochondria against Dysfunction Initiated by Oxidative Stress by Decreasing Complex I Activity. Mitochondrion 2018, 38, 31-40. [CrossRef]

102. Kumfu, S.; Charununtakorn, S.T.; Jaiwongkam, T.; Chattipakorn, N.; Chattipakorn, S.C. Humanin Prevents Brain Mitochondrial Dysfunction in a Cardiac Ischaemia-Reperfusion Injury Model: Humanin and Brain after Cardiac Ischaemia-Reperfusion Injury. Exp. Physiol. 2016, 101, 697-707. [CrossRef] [PubMed]

103. Kumfu, S.; Charununtakorn, S.T.; Jaiwongkam, T.; Chattipakorn, N.; Chattipakorn, S.C. Humanin Exerts Neuroprotection During Cardiac Ischemia-Reperfusion Injury. J. Alzheimer's Dis. 2018, 61, 1343-1353. [CrossRef]

104. Sharp, T.E.; Gong, Z.; Scarborough, A.; Goetzman, E.S.; Ali, M.J.; Spaletra, P.; Lefer, D.J.; Muzumdar, R.H.; Goodchild, T.T. Efficacy of a Novel Mitochondrial-Derived Peptide in a Porcine Model of Myocardial Ischemia/Reperfusion Injury. JACC Basic Transl. Sci. 2020, 5, 699-714. [CrossRef] [PubMed]

105. Ren, L.; Li, Q.; You, T.; Zhao, X.; Xu, X.; Tang, C.; Zhu, L. Humanin Analogue, HNG, Inhibits Platelet Activation and Thrombus Formation by Stabilizing Platelet Microtubules. J. Cell Mol. Med. 2020, 24, 4773-4783. [CrossRef] [PubMed]

106. Gilon, C.; Gitlin-Domagalska, A.; Lahiani, A.; Yehoshua- Alshanski, S.; Shumacher-Klinger, A.; Gilon, D.; Taha, M.; Sekler, I.; Hoffman, A.; Lazarovici, P. Novel Humanin Analogs Confer Neuroprotection and Myoprotection to Neuronal and Myoblast Cell Cultures Exposed to Ischemia-like and Doxorubicin-Induced Cell Death Insults. Peptides 2020, 134, 170399. [CrossRef]

107. McGowan, J.V.; Chung, R.; Maulik, A.; Piotrowska, I.; Walker, J.M.; Yellon, D.M. Anthracycline Chemotherapy and Cardiotoxicity. Cardiovasc. Drugs Ther. 2017, 31, 63-75. [CrossRef]

108. Lue, Y.; Gao, C.; Swerdloff, R.; Hoang, J.; Avetisyan, R.; Jia, Y.; Rao, M.; Ren, S.; Atienza, V.; Yu, J.; et al. Humanin Analog Enhances the Protective Effect of Dexrazoxane against Doxorubicin-Induced Cardiotoxicity. Am. J. Physiol. Heart Circ. Physiol. 2018, 315, H634-H643. [CrossRef] [PubMed]

109. Wu, M.; Shi, H.; He, Y.; Yuan, L.; Qu, X.; Zhang, J.; Wang, Z.; Cai, H.; Qi, J. Colivelin Ameliorates Impairments in Cognitive Behaviors and Synaptic Plasticity in APP/PS1 Transgenic Mice. J. Alzheimer's Dis. 2017, 59, 1067-1078. [CrossRef]

110. Zhao, H.; Feng, Y.; Wei, C.; Li, Y.; Ma, H.; Wang, X.; Cui, Z.; Jin, W.-N.; Shi, F.-D. Colivelin Rescues Ischemic Neuron and Axons Involving JAK/STAT3 Signaling Pathway. Neuroscience 2019, 416, 198-206. [CrossRef]

111. Solanki, A.; Smalling, R.; Parola, A.H.; Nathan, I.; Kasher, R.; Pathak, Y.; Sutariya, V. Humanin Nanoparticles for Reducing Pathological Factors Characteristic of Age-Related Macular Degeneration. Curr. Drug Deliv. 2019, 16, 226-232. [CrossRef]

112. Pożarowska, D.; Pożarowski, P. The Era of Anti-Vascular Endothelial Growth Factor (VEGF) Drugs in Ophthalmology, VEGF and Anti-VEGF Therapy. CEJOI 2016, 3, 311-316. [CrossRef] 
113. Gottardo, M.F.; Pidre, M.L.; Zuccato, C.; Asad, A.S.; Imsen, M.; Jaita, G.; Candolfi, M.; Romanowski, V.; Seilicovich, A. BaculovirusBased Gene Silencing of Humanin for the Treatment of Pituitary Tumors. Apoptosis 2018, 23, 143-151. [CrossRef] [PubMed]

114. Nan, A.; Chen, L.; Zhang, N.; Jia, Y.; Li, X.; Zhou, H.; Ling, Y.; Wang, Z.; Yang, C.; Liu, S.; et al. Circular RNA CircNOL10 Inhibits Lung Cancer Development by Promoting SCLM1-Mediated Transcriptional Regulation of the Humanin Polypeptide Family. Adv. Sci. 2019, 6, 1800654. [CrossRef] 